\title{
MISI PROPETIK PENDIDIKAN ISLAM: MEMBENTUK KARAKTER MENUJU TRANSFORMASI SOSIAL MEMBANGUN PERADABAN
}

\author{
Askar \\ STAIN Datokarama Palu, Jl. Diponegoro No. 23 Palu \\ E-mail: askar@yahoo.com
}

\begin{abstract}
Abstrak: Peradaban yang gemilang akan dapat diraih jika manusia mampu melakukan transformasi diri sebagai modal untuk melakukan transformasi sosial, sedangkan transformasi sosial akan dapat terjadi jika manusia memiliki karakter dan kepribadian yang kuat untuk menghadapi dinamika zaman. Misi kenabian pendidikan Islam adalah mendidik manusia untuk memiliki karakter atau akhlak mulia dan kesadaran kenabian, yakni kesadaran untuk membangun tatanan kehidupan yang maju dan beradab, menegakkan prinsip-prinsip kemanusian universal yang dibangun di atas etika tauhidik yang murni dan kuat, mengembangkan ilmu pengetahuan dan teknologi yang menjamin kelangsungan peradaban manusia.
\end{abstract}

Abstract: The high civilization will be achieved if humans are able to transform themselves as the capital for social transformation, while the social transformation will occur if humans have a strong character and personality to deal with the dynamics of the times. The prophetic mission of Islamic education is to educate people to have a noble character or prophetic consciousness, that is the awareness to build an advanced and civilized life, upholding the universal human principles based on the pure and strong theological ethics, and developing science and technology which ensures the continuity of human civilization.

Kata Kunci: karakter, transformasi sosial, kemajuan dan peradaban 


\section{PENDAHULUAN}

Pendidikan Islam sejatinya mengantarkan manusia memiliki seperangkat kemampuan untuk membaca "tanda-tanda" Tuhan, baik di dalam kitab suci (ayat-ayat qauliyyah) maupun di alam raya (ayat-ayat kauniyyah). Hal ini dimaksudkan agar manusia memiliki kemampuan membangun sinergi dialogis antara ilmu dan agama. Al-Qur'an dan ilmu harus senantiasa disandingkan untuk membaca realitas manusia dengan segala dinamikanya dan realitas alam dengan segala gejalanya. ${ }^{1}$ Agama di satu sisi tidak bisa melepaskan diri dari ilmu pengetahuan dan ilmu pengetahuan tidak bisa berkembang bebas tanpa kawalan agama.

Kemampuan membaca tanda-tanda Tuhan merupakan kunci utama lahirnya manusia yang berkesadaran. Manusia berkesadaran adalah manusia yang yang sadar diri, sadar alam, dan sadar Tuhan ( $\bar{u} l \bar{u}$ al-albāb). Orang-orang $\bar{u} l \bar{u}$ al-albāb adalah orang-orang yang selalu berzikir dan berpikir. Objek zikir adalah Allah dan objek pikir adalah makhluk-makhluk Allah berupa fenomena alam. Pengenalan kepada Allah lebih banyak dilakukan oleh kalbu, sedangkan pengenalan alam didasarkan pada penggunaan akal, yaitu berpikir. Akal memiliki kebebasan seluasluasnya untuk memikirkan fenomena alam, tetapi memiliki keterbatasan dalam memikirkan zat Allah. Sinergi seperti inilah yang melahirkan manusia-manusia berilmu tetapi tetap tunduk dan patuh kepada Allah. ${ }^{2}$

Manusia $\bar{u} l \bar{u}$ al-albāb juga ditandai dengan adanya karakter yang sangat kuat sebagai modal untuk menunaikan tugas kehalifahannya. Karakter yang kuat sangat penting artinya dalam hidup dan kehidupan manusia, karena karakter tidak hanya menjadi titik poros yang mencerminkan akhlak anak bangsa,

${ }^{1}$ Askar, Integrasi Keilmuan di Lembaga Pendidikan Menengah; Studi pada Madrasah Aliyah Negeri 2 Model Palu. Disertasi tidak diterbitkan (Makassar: PPs UIN Alauddin, 2010), h. 60

${ }^{2}$ M. Quraish Shihab, Tafsir Al-Misbah, Pesan, Kesan dan Keserasian AlQur'an. Volume 2 (Jakarta: Lentera Hati, 2000), h. 290-291. 
tetapi juga menjadi proses pencarian watak bangsa dan menjadi poros utama titik balik kesuksesan pembangunan peradaban bangsa. ${ }^{3}$ Realitas menunjukkan bahwa orang-orang atau negaranegara yang berkarakter kuat ternyata memiliki kemampuan untuk menjadi pemimpin sekaligus menjadi lokomotif peradaban.

Meskipun demikian diakui atau tidak, pendidikan Islam yang ada sekarang ini masih menampilkan separuh wajah dari misi pendidikan Islam yang sesungguhnya. Pendidikan Islam sekarang ini masih berkutat pada pembacaan tanda-tanda Tuhan yang ada dalam kitab suci (ayat-ayat qauliyyah). Akibatnya lebih lanjut adalah pendidikan Islam terlalu banyak menghabiskan energi untuk membicarakan perkara-perkara keakhiratan, tetapi melupakan masalah keduniaan yang nyata-empiris, terlalu beraksentuasi pada kajian keislaman klasik daripada kajian keislaman kontemporer, banyak berbicara tentang ketuhanan tetapi mengabaikan problem-problem kemanusiaan yang setiap hari melilit umat manusia. Kondisi seperti ini berakibat pada semakin terpuruknya peradaban manusia dan tercabutnya moralitas agama dari masyarakat yang semakin korup dan semakin jauhnya etika kesalehan publik.

Tulisan ini berusaha untuk menganalisis misi dan watak pendidikan Islam yang dikembangkan oleh Nabi Muhammad, yang kemudian dalam realitas sejarah berhasil memberdayakan masyarakat muslim ketika itu untuk melakukan transformasi sosial dan pada akhirnya sukses membangun peradaban yang sangat maju.

\section{MISI PROPETIK PENDIDIKAN ISLAM}

Misi pendidikan Islam tidak terlepas dari misi utama Nabi yang diutus oleh Allah untuk memperbaiki karakter dan perilaku ummat. Perbaikan karakter dan perilaku merupakan bagian

${ }^{3}$ Pendidikan Karakter Sebagai Pondasi Kesuksesan Peradaban Bangsa, http://www.dikti.go.id, diakses tanggal 2 April 2011 
sangat penting untuk membangun kualitas hidup dan peradaban manusia. Membentuk manusia agar memiliki keseimbangan sinergis antara jasmaniah dan ruhaniah, keseimbangan kemampuan antara pembacaan tanda-tanda Tuhan di dalam kitab suci (ayat-ayat qauliyyah) dan tanda-tanda Tuhan yang ada di alam raya (ayat-ayat kauniyyah).

Misi sentral kependidikan Nabi Muhammad saw. adalah menanamkan akidah tauhid yang benar, mendidik manusia untuk memahami seluruh fenomena alam dan kemanusiaan secara holistik; nembentuk manusia yang memiliki kualitas yang seimbang antara iman, ilmu dan amal, cakap lahiriah maupun batiniah, kualitas yang seimbang antara emosional, rasional, dan spiritual; menegakkan masyarakat yang adil, sehat, harmonis, sejahtera secara material dan spiritual; dan mengembangkan kualitas kehidupan manusia, menyucikan moral membekali manusia modal yang diperlukan untuk hidup bahagia di dunia dan bahagia di akhirat. ${ }^{4}$

Inti pendidikan Islam adalah membentuk akhlak yang mulia, membentuk peserta didik yang memiliki keseimbangan hidup dunia dan akhirat, mengarahkan peserta didik untuk memiliki keterampilan kerja dan kemampuan profesional, menumbuhkan semangat ilmiah. membentuk peserta didik untuk memiliki dan memelihara aspek kerohanian dan keagamaan. ${ }^{5}$ Penguasaan ilmu pengetahuan dan teknologi harus diimbangi dengan pemahaman keagamaan yang mendalam serta pengamalan agama yang tinggi, sehingga memungkinkan peserta didik selalu mengembangkan pengetahuan dalam koridor ajaran agama.

\footnotetext{
${ }^{4}$ Azyumardi Azra, Pendidikan Islam; Tradisi dan Modernisasi Menuju Millenium Baru (Jakarta: Logos Wacana Ilmu, 1999), h. 55-56.

${ }^{5}$ Muhammad 'Ațiyah al-Abrāsyī, al-Tarbiyyah al-Islāmiyah Wa Falāsifatuhāà (Kairo: Isā al-Bābī al-Halabī, 1969), h. 71.
} 
Pendidikan Islam hadir bukan untuk mengajarkan agama yang teralienasi dari konteks, tetapi aktif dalam penyelesaian problem realitas. Sejak awal kedatanganya, ajaran Islam hadir untuk selalu mengentas manusia dari manusia yang berperadaban rendah menuju manusia yang berperadaban tinggi. Mengentas manusia dari problem peyimpangan tauhid menuju tauhid yang murni kepada Allah sebagaimana dilakukan Nabi Muhammad saw. di Mekah dan kemudian membentuk kehidupan sosial masyarakat yang mengedepankan semangat egalitarian dan persamaan sewaktu Nabi berada di Madinah. Membangan masyarakat yang menghargai hak-hak perempuan dan anak-anak, mengentaskan kemiskinan, menumbuhkan kohesi sosial dalam semangat silaturrahim dan semangat tolong-menolong melalui berbagai mekanisme ajaran agama seperti zakat, infak dan sadakah, dan mengembangkan semangat kemanusiaan universal.

Pendidikan Islam sejatinya merupakan proses untuk memanusiakan manusia, dalam konteks ini ada dua agenda penting yakni proses pemanusiaan dan proses kemanusiaan. Proses pemanusiaan adalah sebuah agenda pendidikan untuk menjadikan manusia bernilai secara kemanusiaan, membentuk manusia menjadi insan sejati, memiliki dan menjunjung tinggi tata nilai etik dan moral, memiliki semangat spiritualitas. Proses kemanusian adalah sebuah agenda pendidikan untuk mengangkat martabat manusia melalui penguasaan ilmu pengetahuan dan teknologi, serta keterampilan profesional yang dapat mengangkat harkat dan martabatnya sebagai manusia. ${ }^{6}$

Misi utama kependidikan Nabi adalah pembentukan karakter yang bermula dari penanaman tauhid kepada Allah yang Maha Esa, kemudian dibarengi dengan pembentukan karakter positif lainnya sebagai basis untuk membangun pribadi yang kuat baik secara akidah maupun mental untuk menghadapi dinamika

${ }^{6}$ Sudarwan Danim, Agenda Pembaruan Sistem Pendidikan (Yogyakarta: Pustaka Pelajar, 2006), h. 4. 
kehidupan sosial. Setelah membangun karakter, Nabi mengembangkan tatanan kehidupan sosial kemasyarakatan, kehidupan politik dan ekonomi serta pengembangan ilmu pengetahuan melalui pendidikan. Ini menunjukkan bahwa pendidikan seyogyanya terlebih dahulu mengembangkan karakter dan kepribadian peserta didik kemudian mengembangkan ilmu pengetahuan dan teknologi.

\section{KARAKTER DAN KEMAJUAN PERADABAN}

Karakter merujuk pada cara berpikir dan berperilaku yang menjadi ciri khas tiap individu untuk hidup dan bekerjasama, baik dalam lingkup keluarga, masyarakat, maupun bangsa dan negara. Individu yang berkarakter baik adalah individu yang dapat membuat keputusan dan siap mempertanggungjawabkan setiap akibat dari keputusan yang ia buat.

Karakter seseorang terwujud dalam kesatuan yang esensial dengan perilaku dan sikap hidup yang dimilikinya. Karakter merupakan sesuatu yang mengkualifikasi seorang pribadi. Karakter menjadi identitas yang mengatasi pengalaman kontingen yang selalu berubah. Dari kematangan karakter inilah, kualitas seorang pribadi diukur. ${ }^{8}$ Karakter menjadi aspek yang sangat menentukan bagi seseorang dalam mengembangkan diri, baik dalam aspek mental dan moral yang akan menentukan peran dan dinamika sosial seseorang dalam kehidupannya.

Michael Josephson pendiri Josephson Institut of Etihc di Amerika, merumuskan bahwa secara garis besar ada enam pilar karakter (the six pillars of character) yang semestinya ditumbuh kembangkan dalam diri peserta didik, yaitu; 1) kepercayaan (trustworthiness), berlaku jujur, terpercaya, sesuainya kata dengan perbuatan, berani karena benar, membangun reputasi

\footnotetext{
${ }^{7}$ Suyanto, Urgensi Pendidikan Karakter, http://mandikdasmen.kemdiknas. go.id, diakses tanggal, 1 April 2011.

${ }^{8}$ Doni Koesoema, A. Pendidikan Karakter, http://www.asmakmalaikat. com/go/artikel/pendidikan/umum1.htm, diakses tanggal 2 April 2011.
} 
yang baik, mencintai keluarga dan setia pada negara; 2) Sikap hormat (respect), hormat terhadap orang lain, taat hukum, toleran dalam perbedaan, berlaku sopan dan berbahasa santun, empatik, tidak menjadi ancaman bagi orang lain, dan bersikap damai; 3) bertanggung jawab (responsibility), berorientasi masa depan, tekun dalam kebaikan, disiplin dan mawas diri, berpikir sebelum bertindak dan siap menerima konsekuensi tindakan, bertanggung jawab atas perkataan dan perbuatannya, menjadi contoh bagi orang lain; 4) bersikap adil (fairness), bertindak sesuai aturan, berpikiran terbuka dan mendengarkan orang lain, tidak mengeksploitasi orang lain, meperlakukan semua orang dengan adil, 5) penuh perhatian (caring), perhatian dan penuh kasih sayang, peduli terhadap orang lain, memiliki sikap memaafkan, memberi bantuan pada orang yang membutuhkan, 6) menjadi warga negara yang baik (citizenship), memasyarakat, mampu bekerja sama, menghormati orang lain, mencintai dan melindungi lingkungan, rela berkorban. ${ }^{9}$

UU No 20 Tahun 2003 Tentang Sistem Pendidikan Nasional pada Pasal 3, mengamanatkan bahwa pendidikan nasional berfungsi mengembangkan kemampuan dan membentuk karakter serta peradaban bangsa yang bermartabat dalam rangka mencerdaskan kehidupan bangsa. Pendidikan Nasional bertujuan untuk mengebangkan potensi peserta didik agar menjadi manusia yang beriman dan bertakwa kepada Tuhan Yang Maha Esa, berakhlak mulia, sehat, berilmu, cakap, kreatif, mandiri, dan menjadi warga negara yang demokratis serta bertanggung jawab. ${ }^{10}$

Amanah UU Sisdiknas tahun 2003 tersebut menunjukkan bahwa esensi Pendidikan Nasional adalah membentuk karakter anak bangsa yang berperadaban dan berkepribadian. Pendidikan

\footnotetext{
${ }^{9}$ Michael Josepshon, The Six Pillars of Character, http://charactercounts. org/sixpillars.html, diakses tanggal 6 April 2011.

${ }^{10}$ Undang-Undang Sistem Pendidikan Nasional No. 20 tahun 2003 (Jakarta: Departemen Agama RI, 2007), h. 2
} 
nasional bertujuan untuk membentuk anak bangsa Indonesia yang cerdas, dan juga berkarakter, sehingga nantinya akan lahir generasi bangsa yang tumbuh berkembang dengan karakter yang bernapas nilai-nilai luhur bangsa serta agama. ${ }^{11}$ Keberhasilan Pendidikan Nasional tidak hanya dapat dilihat pada panguasaan ilmu pengetahuan tetapi juga anak bangsa yang berpendidikan dapat menujukkan karakter yang sesuai dengan budaya bangsa yang merujuk pada nilai-nilai agama yang tumbuh dan berkembang di Indonesia dan nilai-nilai Pancasila.

Arah Pendidikan Nasional memiliki arah yang sama dengan tujuan pendidikan yang dicita-citakan oleh UNESCO, yang bertumpu pada empat pilar pendidikan, yakni learning to know, learning to do, learning to live together dan learning to be. ${ }^{12}$ Menurut pilar-pilar tersebut, pendidikan selain berupaya untuk mengajarkan peserta didik berbagai ilmu pengetahuan sehingga mereka mengetahui dan menguasai ilmu pengetahuan yang dipelajarinya tersebut, juga penting untuk membekali peserta didik kemampuan untuk menerapkan dan mempraktikkan ilmu pengetahuan yang telah diketahuinya tersebut sehingga dapat membantu peserta didik memiliki kemampuan dinamis untuk menghadapi masa depannya. Untuk hal tersbut diperlukan kecakapan-kecakapan sosial bagi peserta didik sehingga mampu membangun komunikasi antar sesama, mampu memotivasi diri dan mengelola emosinya sehingga dapat menghindari konflik dan memiliki keterampilan sosial yang memadai. Tidak hanya itu, pendidikan juga harus mampu mengembangkan kepribadian peserta didik secara utuh sehingga ia dapat menjadi dirinya sendiri, yakni kepribadian yang tidak saja memiliki intelegnsi, dan kecakapan sosial, tetapi juga memiliki kemampuan dan kepekaan, memiliki tanggung jawab, komitmen hidup yang tinggi, memiliki

\footnotetext{
${ }^{11}$ Suyanto,

Urgensi

Pendidikan

Karakter,

http://mandikdasmen.kemdiknas. go.id, diakses tanggal 1 April 2011.

${ }^{12}$ The International Comission on Education for Twenty-first Century, Treasure Within (Paris: UNESCO Publishing, 1996), h. 85.
} 
nilai-nilai spiritual sehingga ia selalu memetik makna di balik segala dinamika kehidupan yang ia hadapi.

Tujuan Pendidikan Nasional, maupun arah pendidikan yang dicitakan oleh UNESCO merupakan implementasi dari misi propetik pendidikan Islam. Misi kenabian kependidikan Islam tidak hanya berporos pada pengembangan intelektual dan transformasi ilmu pengetahuan, tetapi juga mengarah pada proses pemberdayaan peserta didik. Proses pemberdayaan adalah pengembangan berbagai kemampuan dalam diri seperti kemampuan untuk menghadapi dan memecahkan masalah, kemampuan dan kecakapan berkomunikasi, kemampuan untuk membangun hubungan sosial dan interpersonal, kemandirian, etika dan estetika, kedalaman spiritualitas. Kemampuan atau kompetensi seperti ini tidak semata diperoleh melalui mata pelajaran yang dipelajari oleh peserta didik di kelas, tetapi juga dapat diperoleh melalui pengembangan berbagai kemampuan secara holistik dan integratif. Di sinilah letak pentingnya pengembangan kompetensi lintas kurikulum sebagai bekal bagi peserta didik untuk menghadapi berbagai kemungkinan masa depannya.

Tujuan pembelajaran dalam pendidikan yang bermisi propetik, tidak hanya berorientasi pada proses transformasi ilmu pengetahuan (transfer of knowledge) semata, tetapi juga harus diarahkan pada proses transfer nilai (transfer of value). Dalam konteks yang demikian maka seorang guru tidak hanya sibuk mempersiapkan berbagai materi serta strategi pembelajaran, tetapi juga seorang guru harus mampu menjadi teladan yang baik bagi peserta didik, baik dalam berpikir, bertindak dan berkomunikasi. Guru harus mampu menjadi motivator yang baik, menjadi patron dalam komunikasi hubungan sosial. Guru harus mampu mengembangkan kemampuan inter dan antar personal perserta didiknya. 
Pembentukan karakter tidak saja untuk memperkuat jati diri dan identitas anak bangsa, tetapi juga untuk mengembangkan kepribadian yang berkarakter untuk memasuki pergaulan internasional yang semakin mengglobal. Realitas menunjukkan bahwa negara-negara yang memiliki karakter yang kuat, ternyata memiliki peradaban yang tinggi. Ini menunjukkan bahwa kemampuan kompetitif bangsa hanya dapat dicapai melalui karakter yang kuat dan beradab. ${ }^{13}$ Sebagai potret selintas dapat dikemukakakn bahwa negara yang memiliki karakter seperti Amerika, Jepang, Iran adalah sebagian dari contoh negara-negara dengan karakternya masing-masing yang ternyata mampu membangun dan menunjukkan peradaban yang gemilang.

Dalam konteks individu juga dapat dilihat bahwa pribadipribadi yang berkarakter kuat ternyata memiliki kemampuan kepeminpinan yang juga sangat kuat dan mampu menjadi pelopor ke arah kemajuan peradaban. Dalam konteks ini, dan tanpa menafikan tokoh-tokoh negarawan lain yang berkarakter sangat kuat, dapat dilihat pada pribadi Nabi Muhammad dengan karakternya yang sangat kuat ternyata menjadi pemimpin yang mampu membawa negara yang dipimpinnya untuk meraih kemajuan dan peradaban.

\section{PENDIDIKAN ISLAM DAN TRANSFORMASI SOSIAL}

Jika diurai dan dianalisis lebih lanjut tentang misi kenabian kependidikan Islam, ditemukan bahwa pendidikan Islam berorientasi pada terjadinya transformasi sosial. Transformasi sosial diartikan sebagai perubahan yang menyangkut berbagai aspek kehidupan, seperti tata nilai, pranata sosial, wawasan, cara berpikir, atau kebiasaan yang telah lama terjadi di masyarakat dan sebagainya. Perubahan tersebut ada kalanya sangat mendasar, tetapi bisa juga bersifat umum. Transformasi sosial

\footnotetext{
${ }^{13}$ Miranda Diponegoro Z, dkk. Model Pendidikan Karakter di Universitas Indonesia, http://www.dikti.go.id, diakses tanggal 28 Maret 2011
} 
bukan sekadar perubahan seperti disebutkan di atas, melainkan juga perubahan mutu kehidupan sosial, budaya, politik, dan ekonomi masyarakat. ${ }^{14}$

Pendidikan pada umumnya dan pendidikan Islam khususnya hingga kini masih dipercaya sebagai alat utama untuk mentransformasikan kebudayaan atau memperbaiki sistem sosial..$^{15}$ Kepercayaan yang tinggi ini, disebabkan karena pendidikan penuh dengan berbagai cara dan aktivitas untuk melakukan proses humanisasi, dan karenanya pendidikan dipandang dan diyakini sebagai sebuah proses transformasi sosial menuju perubahan ke arah kemajuan di tengah masyarakat. ${ }^{16}$

Pendidikan harus ditujukan untuk menghasilkan manusia Indonesia yang berani melakukan transformasi sosial, memiliki kecerdasan akademik, berakhlak, dan terampil. Dalam mewujudkan pendidikan yang bisa menjadi motor penggerak perubahan tatanan sosial masyarakat tersebut, diperlukan keseimbangan peran penyelenggaraan antara negara, komunitas, dan keluarga. Alasannya ialah pendidikan menuntut kemitraan dan tanggung jawab semua pemangku kepentingan, termasuk orang tua, komunitas, dan masyarakat luas. ${ }^{17}$

Pendidikan Islam sejak awalnya selalu berorientasi untuk mencetak individu yang berkesadaran kenabian yakni individu yang tidak saja sadar dirinya sebagai hamba Tuhan tetapi juga individu yang sadar sebagai warga manusia dan warga alam. Membentuk individu memiliki kesadaran berkeadaban dan berkemanusiaan akan mengantarkan individu tersebut untuk menjadi warga negara dan warga dunia yang baik, dan bahkan

\footnotetext{
${ }^{14}$ H. Mudjia Rahardjo, Bahasa dan Transformasi Sosial. http://www.uinmalang.ac.id, diakses tanggal 11 Mei 2011.

${ }^{15}$ I. N. Thut \& Don Adams, Educational Patterns in Contemporary Societies (New York: McGraw-Hill Book Company, 1984), h. 1

${ }^{16}$ Akhmad Muhaimin Azzet, Pendidikan Sebagai Proses Transformasi Sosial, http://edukasi.kompasiana.com, diakses tanggal 11 Mei 2011.

${ }^{17}$ Pendidikan untuk Transformasi Sosial, http://www.indonesiaberprestasi. web.id/?p=4442, diakses tanggal 12 Mei 2011.
} 
menjadi hamba Tuhan yang taat. Manusia yang berkesadaran kenabian bertanggung jawab untuk menyelesaikan berbagai persoalan sosial, kritis terhadap persoalan lingkungan dan peradaban yang berbasis pada spiritualitas Islam. Dalam monteks ini pendidikan Islam tidak saja memperhatikan aspek-aspek qidah dan ibadah tetapi juga aspek pengembangan ilmu pengetahuan. Pendidikan Islam sejak awalnya selalu mengedepankan pengembangan karakter dan pribadi yang kuat, dan pada saat yang sama pendidikan Islam juga memperhatikan pengembangan ilmu pengetahuan.

Sebagaimana telah diuraikan sebelumnya bahwa pendidikan Islam ketika di Mekkah lebih menitik beratkan pada penanaman aqidah yang kuat dan murni serta ketaatan beribadah sebagai unsur penting dalam pembentukan karakter, dan ketika di Madinah pendidikan Islam lebih dititik beratkan pada pengembangan ilmu pengetahuan, politik, ekonomi dan sosial. Dengan pola pendidikan seperti ini pendidikan Islam telah mampu membawa masyarakat Islam untuk melakukan tranformasi diri dan bahkan transformasi sosial, mentransformasi masyarakat dari peradaban-peradaban rendah ke peradaban yang yang tinggi, dari peradaban yang tidak berkemanusiaan menuju peradaban yang berkemanusiaan, dari peradaban jahiliyah ke peradaban ilahiyah.

\section{PENUTUP}

Pola yang diterapkan oleh pendidikan Islam untuk melakukan tranasformasi sosial membangun peradaban yang berkemanusiaan universal dengan menitikberatkan pada penanaman akidah dan ibadah serta pembentukan karakter atau akhlakul karimah dan kemudian pengembangan ilmu pengetahuan dan teknologi serta penguasaan keterampilan. Ini berarti jika pendidikan nasional Indonesia diorientasikan untuk mampu melakukan transformasi sosial dan membangun peradaban maka pendidikan di Indonesia semestinya 
mengedepankan pembentukan karakter yang kemudian dibarengi dengan pengembangan iptek dan keterampilan. Ini berarti bahwa kurikulum pendidikan harus mengedepankan atau paling tidak memberi porsi yang seimbang antara pengembangan karakter, dengan pengembangan ilmu pengetahuan dan teknologi serta peningkatan keterampilan.

\section{DAFTAR PUSTAKA}

al-Abrāsȳ̄, Muhammad 'Ațiyah. al-Tarbiyyah al-Islāmiyah Wa Falāsifatuhā, Kairo: 'Isā al-Bābi al-Ḥalabī, 1969.

Askar, Integrasi Keilmuan di Lembaga Pendidikan Menengah; Studi pada Madrasah Aliyah Negeri 2 Model Palu. Disertasi tidak diterbitkan Makassar: PPs UIN Alauddin, 2010.

Azzet, Akhmad Muhaimin. Pendidikan Sebagai Proses Transformasi Sosial, http://edukasi.kompasiana.com, diakses tanggal 11 Mei 2011.

Azra, Azyumardi. Pendidikan Islam; Tradisi dan Modernisasi Menuju Millenium Baru. Jakarta: Logos Wacana Ilmu, 1999.

Danim, Sudarwan. Agenda Pembaruan Sistem Pendidikan, Yogyakarta: Pustaka Pelajar, 2006.

Diponegoro Z, Miranda dkk. Model Pendidikan Karakter di Universitas Indonesia, http://www.dikti.go.id, di akses tanggal 28 Maret 2011.

Josepshon, Michael. The Six Pillars of Character,_http://charactercounts. org/sixpillars.html, diakses tanggal 6 April 2011.

Koesoema, A Doni. Pendidikan Karakter, http://www.asmakmalaikat. com/go/artikel/pendidikan/umum1.htm, diakses tanggal 2 April 2011.

Pendidikan Karakter Sebagai Pondasi Kesuksesan Peradaban Bangsa, http://www.dikti.go.id. diakses, tanggal 2 April 2011.

Pendidikan untuk Transformasi Sosial, http://www.indonesia berprestasi.web.id/?p=4442, diakses tanggal 12 Mei 2011

Rahardjo, H. Mudjia. Bahasa dan Transformasi Sosial. http://www.uinmalang.ac.id, diakses tanggal 11 Mei 2011. 
Vol. 8, No.1, Juni 2011: 175-188

Shihab, M. Quraish. Tafsir Al-Misbah, Pesan, Kesan dan Keserasian AlQur'an. Vol. 2, Jakarta: Lentera Hati, 2000.

Suyanto, Urgensi Pendidikan Karakter, http://mandikdasmen. kemdiknas.go.id, diakses tanggal, 1 April 2011.

The International Comission on Education for Twenty-first Century, Treasure Within, Paris: UNESCO Publishing, 1996.

Thut, I. N. \& Adams, Don. Educational Patterns in Contemporary Societies, New York: McGraw-Hill Book Company, 1984.

Undang-Undang Sistem Pendidikan Nasional No. 20 Tahun 2003, Jakarta: Departemen Agama RI, 2007. 